\title{
"Effects of brand innovation and marketing dynamic capability on the performance of international hotels"
}

\begin{tabular}{|c|c|c|}
\hline AUTHORS & $\begin{array}{l}\text { Evo Sampetua Hariandja (D) } \\
\mathbb{R} \\
\text { Lusiana Sartika }\end{array}$ & \\
\hline ARTICLE INFO & $\begin{array}{l}\text { Evo Sampetua Hariandja and L } \\
\text { and marketing dynamic capabili } \\
\text { Innovative Marketing, } 18(1), 63\end{array}$ & $\begin{array}{l}\text { 2). Effects of brand innovation } \\
\text { ce of international hotels. } \\
\text { m.18(1).2022.06 }\end{array}$ \\
\hline DOI & http://dx.doi.org/10.21511/im.18 & \\
\hline RELEASED ON & Thursday, 10 February 2022 & \\
\hline RECEIVED ON & Sunday, 23 May 2021 & \\
\hline ACCEPTED ON & Friday, 04 February 2022 & \\
\hline JOURNAL & "Innovative Marketing " & \\
\hline ISSN PRINT & $1814-2427$ & \\
\hline ISSN ONLINE & $1816-6326$ & \\
\hline PUBLISHER & LLC “Consulting Publishing Cor & erspectives" \\
\hline FOUNDER & LLC “Consulting Publishing Cor & erspectives" \\
\hline$\sigma^{\circ}$ & $B$ & $\begin{array}{l}\text { ニニ } \\
\text { 三ニ }\end{array}$ \\
\hline NUMBER OF REFERENCES & NUMBER OF FIGURES & NUMBER OF TABLES \\
\hline 54 & 1 & 11 \\
\hline
\end{tabular}

(c) The author(s) 2022. This publication is an open access article. 


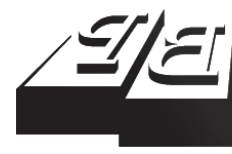

\section{BUSINESS PERSPECTIVES}

(O)

LLC "CPC "Business Perspectives" Hryhorii Skovoroda lane, 10, Sumy, 40022, Ukraine www.businessperspectives.org
Received on: $23^{\text {rd }}$ of May, 2021 Accepted on: $4^{\text {th }}$ of February, 2022 Published on: $10^{\text {th }}$ of February, 2022

(c) Evo Sampetua Hariandja, Lusiana Sartika, 2022

Evo Sampetua Hariandja, Dr., Assistant Professor, Faculty of Economics and Business, Department of Management, Universitas Pelita Harapan, Indonesia. (Corresponding author)

Lusiana Sartika, Faculty of Economics and Business, Department of Management, Universitas Pelita Harapan, Indonesia.

\title{
EFFECTS OF BRAND
}

INNOVATION AND MARKETING

DYNAMIC CAPABILITY

ON THE PERFORMANCE

OF INTERNATIONAL HOTELS

\begin{abstract}
The Covid-19 epidemic has resulted in a dramatic decline in hotel public consumption. Hotel performance must be enhanced through the use of a hotel marketing strategy to compete with others. The aim of this paper is to examine the relationship between the innovation of the brand, dynamic capability of marketing, brand communication, brand experience, and brand performance in Indonesian 3-5 star international hotels. The data for this study were acquired using an electronic questionnaire on Google Forms from 530 customers who stayed in hotels throughout Indonesia prior to and during the Covid-19 pandemic. Smart-PLS 3.2.9 was used to analyze the data using the outer model and the inner model. The findings indicated as follows: brand innovation has a positive effect on brand communication; dynamic marketing capability has a positive influence on brand communication; brand communication directly has a positive effect on brand experience; brand experience significantly has a positive effect on brand performance; brand communication directly has a positive effect on brand performance; brand innovation has a positive influence on brand performance, and dynamic marketing capability has a positive effect on brand performance. This study contributes to the worldwide hotel strategy's global marketing efforts in order to compete and improve performance in an increasingly competitive hotel business.
\end{abstract}

Keywords

JEL Classification brand, innovation, performance, dynamic capability, hotel, Indonesia

M31, Z32

\section{INTRODUCTION}

Following the emergence of Covid-19, some countries enacted restrictions such as locks, border closures, and guarding distance legislation, all of which damaged the world economy, particularly the tourism industry, which includes the hotel industry (Japutra \& Situmorang, 2021). Furthermore, locking down a country affects people's income, which reduces public consumption of tourism, notably hotel spending (Anguera-Torrell et al., 2021).

Indonesia has 72 international hotel chains and five local hotel chains, indicating that Indonesian and foreign guests choose international star hotels over domestic star hotels, owing to the country's greater quantity of international star hotels (BPS, 2020). However, according to Maulana Yusran, Secretary-General of Persatuan Hotel dan Restoran Indonesia (PHRI), the Covid-19 pandemic has wreaked havoc on Indonesia's hotel and restaurant business with around 1,600 establishments ceasing operations since March 2019 (Idris, 2020). 
To remain competitive in today's dynamic worldwide hotel industry, which is intrinsically linked to tourism, hotels must first acquire clients (Wiastuti et al., 2020). The hotel sector must include innovative approaches for providing better service that visitors from all over the world highly value. This concept should be implemented in the hotel and tourism industries (Roespinoedji et al., 2019). Hotels should offer novel services to their clients by leveraging their service innovation skills and using dynamic marketing capability (DMC) to conduct successful marketing campaigns for their consumer segments in dynamic marketplaces (Hariandja, 2016b). International hotels should be able to expand their DMCs in order to maintain a competitive edge (Elsharnouby \& Elbanna, 2021). A business that aspires to thrive in this increasingly challenging climate must constantly strengthen its capacity for innovation. When new ideas are developed and applied, innovation occurs (Jiménez-Jiménez \& Sanz-Valle, 2011).

With the global Covid-19 pandemic in full swing and multiple multinational hotel chains in Indonesia, hotels must utilize intelligent marketing tactics to stay afloat. This study assembles empirical facts to determine the critical assessment of brand innovation, brand communication, brand experience, and dynamic marketing competency to enhance the brand performance of 3-5 star international hotels in Indonesia.

\section{LITERATURE REVIEW, AIMS AND HYPOTHESES}

\subsection{Brand innovation}

Through every interaction of innovative concepts, brand innovation aims to convey both direct and indirect experiences to consumers. When doing brand innovation, the vital thing to do in the beginning is to win consumer trust and value to build the brand (Chien, 2013). In addition, brand innovation is to increase brand value, service products, and experience by integrating the company's competence with the participation of its consumers, which is currently snowballing in the market and becoming an attractive trend (Hsieh \& Chang, 2016).

Hotels are compelled to innovate somehow because of the intense competition in the hotel industry. The ability to build brand innovation expectations is dependent on the company's ability to effectively and persuasively convey this knowledge about its brand to target consumers. Branding can promote creativity over time, offer an innovation more credibility and legitimacy, boost its profile, and make communication more feasible and efficient (Aaker, 2007). If a company can communicate this about its brand to target audiences efficiently and persuasively, it will be able to create brand innovation expectations (Pappu \& Quester, 2016).
Being creative and adaptable is needed in the hospitality market climate that has changed due to the Covid-19 pandemic to develop and maintain a company's success. Brand innovation is a brand strategy that can improve brand performance (Grant, 2006). Customers' awareness of brand innovation has been shown to improve brand performance, reinforce a brand, and provide it with a competitive advantage (Fazal-e-Hasan et al., 2019). To improve brand performance, each company employs a different strategy, such as brand extension, the launch of new products, continuous technological growth, and logotype change (Weerawardena et al., 2006).

\subsection{Dynamic Marketing Capability (DMC)}

Marketing capabilities are described as a method of coordinating organizations using the organizational assets and capabilities to understand the clients' need to create a variety of products that are separated from rivals and achieve brand prominence (Hariandja, 2016b). On the other hand, dynamic marketing capabilities allow businesses to liberate themselves from their rigid structures. DMC is composed of three elements. First, market sensing is the ability of a business to accept the ability of its clients, partners, and competitors to interpret, store, and use data, as well as react to advancements and activities in present and futures markets. Following that, market learning, or the capacity to learn, enables an organization 
to maintain a long-term competitive edge over competitors, adjust to a complex and competitive environment, and be receptive to acquiring and combining external information. Learning enables us to identify new opportunities, accounts for redundancy, and incorporates information from the external environment to maximize effectiveness. Finally, consumer targeting and positioning are major considerations. This component integrates its capacity to recognize additional opportunities and then choose the best target market with the resources and strengths of the company (Hariandja, 2016a).

In the marketing industry, dynamic marketing capabilities include new product invention, pricing, advertising, delivery, sales, and relationship marketing (Walugembe et al., 2017). Companies with dynamic marketing capabilities can react rapidly in different markets by improving consumer communication patterns (Hoque et al., 2021). Dynamic marketing capabilities and service innovation capabilities should be combined through marketing communications to communicate with consumers effectively (Hariandja et al., 2014). To maximize efficiency, a firm's more outstanding marketing capabilities should complement one another because then that one capability may reinforce the impact of another in a cross-functional unit (Hoque et al., 2021). Understanding customer and competitor needs, as well as raising industry awareness, marketing skills, and capital, has the potential to increase company performance (Elsharnouby \& Elbanna, 2021). Strong customer relationships are established due to marketing capabilities, which positively affect customer satisfaction and loyalty (Konwar et al., 2017). Therefore, it is possible to create strong positioning and value to preserve their loyalty by developing marketing capabilities, which are essential in organizational performance (Reimann et al., 2021). These skills assist companies in developing effective customer relationships and retaining current customer bases, thus impacting organizational performance (Takahashi et al., 2017).

\subsection{Brand communication}

Brand communication is an integral part of public relations, being a form of marketing. PR must ensure that a brand communication strategy provides a clear message that consumers can easily accept as authentic and relevant (Bhasin, 2021). Brand communication is the process of reducing the gap between consumers and their perceptions of products and services. Brand communication aims to introduce a service or product to an audience so that customers are fully aware of what is available on the market (Asy'ari \& Jayen, 2020). According to Sahin et al. (2011), brand communication is done by businesses with the aim not only to create brand awareness but also to build a respectable image and standardization that the organization must aim for or exceed (Chinomona, 2016).

Companies must communicate the brand to potential customers before consumers remember and experience it. Because of the communicative nature of products, it is essential to recognize this to convey the brand promise and experience accurately (Ngatno, 2017). Brand managers must communicate efficiently and engage with their consumers during the entire buying process and after the consumption experience (Kang et al., 2017). Brand communication is not only based on promotional messages sent through the elements of integrated marketing communication but also involves the experience that a brand provides to its users so that a close relationship is established between the brand and its users (Suharyanti et al., 2019). Communicating with customers will help hotels understand what needs to be changed. Individual customers are influenced by the information given by an organization or company to take action (buy a product), and then tell others based on their experience with the product (Xie et al., 2016). If they have a positive experience when they connect with a brand, they are more likely to be satisfied. Since correlation is found between brand experience and brand loyalty, the more satisfied clients there are, the more faithful customers there would be, and the greater their loyalty, which can influence brand performance (Hussein, 2018).

\subsection{Brand experience}

According to Brakus et al. (2009), brand experiences are described as customers' responses (such as emotions, feelings, awareness) and behavioral tendencies stimulated by brand-related factors found in branding, packaging, communication, and the environment (Coelho et al., 2020). According to 
Wibowo (2011), brand experience is integral to experiential marketing. Consumers create experiences with brands ranging from product search, selecting and buying products in stores, interacting with customer service to using products so that the experience can provide value to the brand (Hanifah et al., 2018).

Providing a unique and memorable brand experience is essential to increasing the success of the performance results (Khan \& Fatma, 2017). Emotions derived from interactions with a specific brand may impact the brand performance outcomes. If consumers remember its brand experience, they will remember the positive feelings associated with that brand, which will affect their intention to return and will minimize the size set by their decision when making potential accommodation choices (Casidy et al., 2018).

\subsection{Brand performance}

Brand performance is often a primary outcome of company operations and overall business strategy. The definition of brand performance shows the consumer strength of a company's brand. In the tourism industry, field research on brand performance mainly assesses and analyzes brand marketing performance and brand performance from visitors' perspectives. Additionally, field research on tourism brand performance commonly focuses on hotel companies and aims to shed light on the connection among other variables affecting hotel brand performance in visitors' eyes (Unurlu \& Uca, 2017).
Financial and non-financial performance are combined to create a brand performance. Market share and profitability are used to evaluate financial brand performance, whereas non-financial brand performance is measured by brand maintenance (Iyer et al., 2018). Customer satisfaction, as well as brand loyalty, have been used to assess the success of non-financial brands. According to Mason et al. (2006), several additional variables that quantify customer satisfaction, the causes of its loyalty, and even the relationship among consumer devotion and performance throughout the hotels and tourism sectors are of significant interest. Based on O'Neill and Xiao (2006), hotel branding would aim to increase brand loyalty among customers and hotel businesses. Furthermore, O'Neill and Mattila (2004) affirmed that consumer loyalty is the most crucial factor to consider when evaluating hotel branding strategies (Liu et al., 2020).

\subsection{Hypotheses}

This study aims to determine the consumer impact of brand innovation, DMC, brand communication, and brand experience on brand performance in 3-5 star international hotels in Indonesia. Based on the available literature, the following hypotheses were developed:

\section{H1: Brand innovation has a favorable effect on brand communication.}

H2: Dynamic marketing capability has a beneficial effect on brand communication.

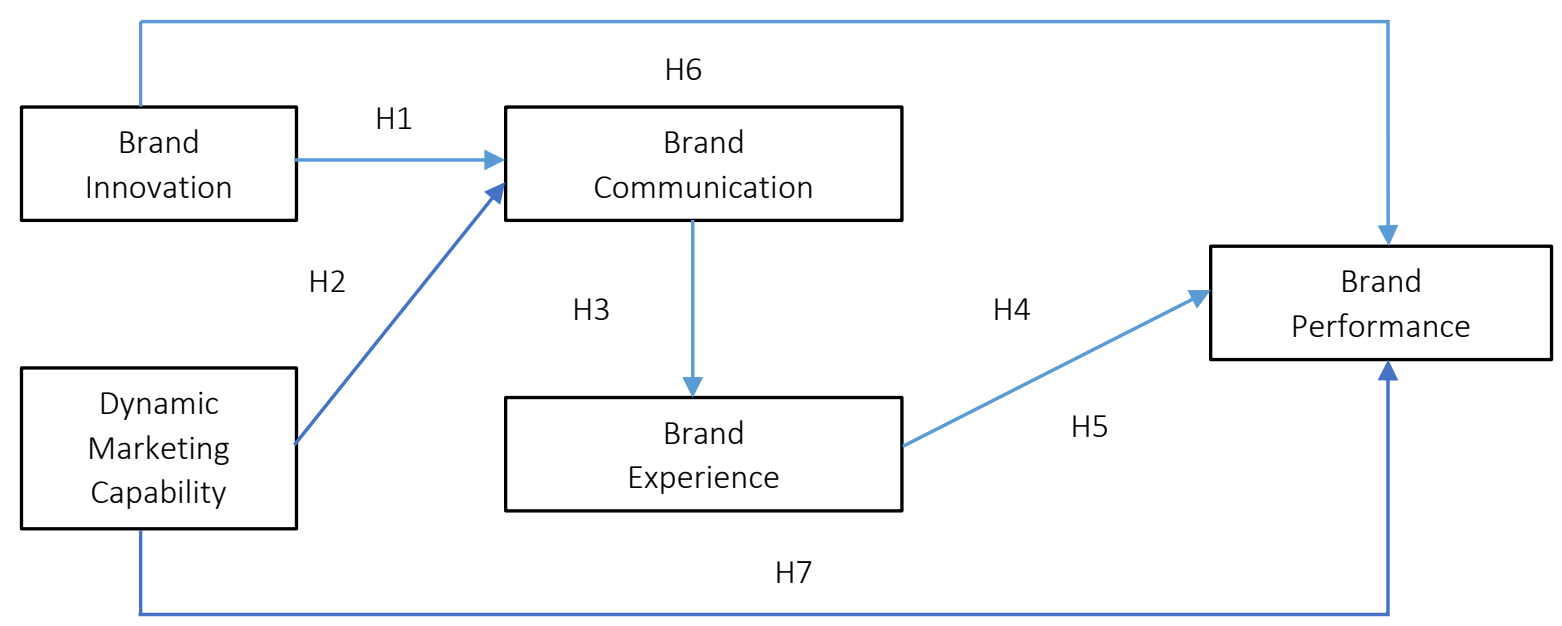

Figure 1. Research framework 
H3: Brand communication has a favorable effect on the brand experience.

H4: Brand experience has a beneficial effect on brand performance.

H5: Brand communication has a favorable effect on brand performance, mediated by brand experience.

H6: Brand innovation has a favorable effect on brand performance.

H7: Dynamic marketing capability and brand performance have a beneficial effect.

The research framework is depicted in Figure 1.

\section{METHODS}

A quantitative research method was used in this study. Since this study aims to figure out how variables are related, descriptive research is used. Brand innovation, brand communication, and DMC are investigated as independent variables that affect brand performance as the dependent variable. Brand experience serves as a mediating variable between brand communication and brand performance. This study examines brand innovation using five scales adapted from Fazal-eHasan et al. (2019) and Shams et al. (2015). DMC variables with market sensing dimension use three scales, market learning dimension uses three scales, and market targeting and positioning dimension uses four scales adapted from Hariandja et al. (2014). Brand communication variables use five scales adapted from Chinomona (2016) and Ngatno (2017). Brand experience uses seven scales adapted from Gómez-Suárez and Veloso (2020). Brand performance variables with brand recommendation dimension use three scales, customer satisfaction dimension uses four scales, brand loyalty dimension uses eight scales, and repurchase dimension uses three scales adapted from Foroudi (2019) and Liu et al. (2020).

The Likert scale was used as the interval measurement scale in this study. The Likert scale is used to determine the extent to which respondents agree or disagree with a question or statement contained in an electronic questionnaire distributed via G-Forms. This study employed judgmental sampling, a type of non-probability sampling. A sample size of 530 participants multiplied by the 53 indicators used was required to conduct the analysis. Individuals who stayed in 3-5 star international hotels in Indonesia before and after the Covid-19 pandemic were surveyed. The questionnaire was completed by most female respondents in the gender group, with a sample size of 62.6 percent from Tangerang, Jakarta, and Bandung. It is essential to emphasize that most of the 272 respondents were $20-24$ years old. These Gen $\mathrm{Z}$ travelers dubbed the next generation, wield surprising influence over family travel decisions (Wiastuti et al., 2020). This is demonstrated by the fact that 80.9 percent of respondents work as college students, 80.6 percent earn less than Rp100.000 per month, and 76.2 percent travel with family as shown in Table A1, Appendix A.

The data were analyzed using the outer and inner models in Smart-PLS 3.2.9. To begin, the outer model's convergent validity, discriminant validity, and reliability were evaluated as shown in Table A3, Appendix A. The inner model is tested for goodness of fit as depicted in Table A4, Appendix A, common method bias, common method variation, VIF, $\mathrm{R}^{2}$, predictive relevance as shown in Table A5, Appendix A, and hypothesis testing.

\section{RESULTS}

\subsection{Measurement model}

Following the actual convergent validity test via the loading factor value, 45 indicators are valid with a loading factor value greater than 0.7 as depicted in Table A2, Appendix A. The results of the convergent validity test using Average Variance Extracted (AVE) indicated that ten variables in this study had a value greater than 0.5 and were thus considered valid. Thus, eleven variables (brand innovation, market sensing, learning, targeting and positioning, brand communication, brand experience, brand recommendation, customer satisfaction, brand loyalty, dynamic marketing capability, brand repurchase, and performance) are declared valid by the convergent validity test conducted using AVE. The AVE value for the dynamic marketing capability variable is 
Table 1. Measurement model

\begin{tabular}{l|c|c|c}
\hline \multicolumn{1}{c}{ Variable } & Cronbach's $\alpha$ & Composite Reliability & Average Variance Extracted (AVE) \\
\hline Brand Communication & 0.883 & 0.914 & 0.681 \\
Brand Experience & 0.870 & 0.900 & 0.562 \\
Brand Innovation & 0.802 & 0.863 & 0.557 \\
\hline Brand Loyalty & 0.913 & 0.930 & 0.624 \\
\hline Brand Performance & 0.945 & 0.951 & 0.519 \\
\hline Brand Recommendation & 0.838 & 0.903 & 0.756 \\
\hline Brand Repurchase & 0.871 & 0.921 & 0.795 \\
\hline Customer Satisfaction & 0.880 & 0.907 & 0.708 \\
\hline Dynamic Capability of Marketing & 0.696 & 0.903 & 0.482 \\
\hline Learning of The Market & 0.716 & 0.831 & 0.622 \\
\hline Sensing of The Market & 0.764 & 0.841 & 0.638 \\
Positioning and Targeting & 0.850 & 0.856 \\
\hline
\end{tabular}

Table 2. HTMT ratio

\begin{tabular}{|c|c|c|c|c|c|}
\hline Variable & $\begin{array}{c}\text { Brand } \\
\text { Communication }\end{array}$ & $\begin{array}{c}\text { Brand } \\
\text { Experience }\end{array}$ & $\begin{array}{c}\text { Brand } \\
\text { Innovation }\end{array}$ & $\begin{array}{c}\text { Brand } \\
\text { Performance }\end{array}$ & DMC \\
\hline \multicolumn{6}{|c|}{ Brand Communication } \\
\hline Brand Experience & 0.815 & & & & \\
\hline Brand Innovation & 0.669 & 0.817 & & & \\
\hline Brand Performance & 0.851 & 0.852 & 0.669 & & \\
\hline DMC & 0.808 & 0.843 & 0.871 & 0.764 & \\
\hline
\end{tabular}

0.482 , which is close to 0.5 . While the AVE should of 0.903 , indicating that dynamic marketing capabe greater than 0.5, Fornell and Larcker (1981) ob- bility is deemed valid.

serve that even when the value is less than 0.5 , and the composite reliability exceeds 0.6 , the construct Following the data in Table 1 , all 12 variables are retains sufficient convergent validity (Huang et al., considered reliable because their values are greater 2013). Additionally, the dynamic marketing capa- than the 0.7 composite reliability rule of thumb. bility variable in composite reliability has a value Additionally, the Learning variable's Cronbach's

Table 3. VIF statistics

\begin{tabular}{|c|c|c|c|c|c|c|c|c|c|}
\hline \multirow{2}{*}{\multicolumn{2}{|c|}{ Brand Innovation }} & \multicolumn{6}{|c|}{ DMC } & \multirow{2}{*}{\multicolumn{2}{|c|}{ Brand Communication }} \\
\hline & & \multicolumn{2}{|c|}{ Market Sensing } & \multicolumn{2}{|c|}{ Market Learning } & \multicolumn{2}{|c|}{$\begin{array}{c}\text { Market Targeting } \\
\text { and Positioning }\end{array}$} & & \\
\hline Item & VIF & Item & VIF & Item & VIF & Item & VIF & Item & VIF \\
\hline INNO1 & 1.478 & SENS2 & 1.364 & LEARN1 & 1.292 & TAPO1 & 1.448 & COMM1 & 2.005 \\
\hline INNO2 & 1.666 & SENS3 & 1.382 & LEARN3 & 1.392 & TAPO2 & 1.468 & COMM2 & 2.085 \\
\hline INNO3 & 1.576 & SENS4 & 1.486 & LEARN4 & 1.406 & TAPO3 & 1.479 & COMM3 & 2.060 \\
\hline INNO5 & 1.618 & & & & & TAPO4 & 1.577 & COMM4 & 2.121 \\
\hline INNO6 & 1.591 & & & & & & & COMM5 & 2.269 \\
\hline \multirow{2}{*}{\multicolumn{2}{|c|}{ Brand Experience }} & \multicolumn{6}{|c|}{ Brand Performance } & \multirow{2}{*}{\multicolumn{2}{|c|}{$\begin{array}{c}\text { Brand } \\
\text { Repurchase }\end{array}$}} \\
\hline & & \multicolumn{2}{|c|}{$\begin{array}{c}\text { Brand } \\
\text { Recommendation }\end{array}$} & \multicolumn{2}{|c|}{ Customer Satisfaction } & \multicolumn{2}{|c|}{ Brand Loyalty } & & \\
\hline Item & VIF & Item & VIF & Item & VIF & Item & VIF & Item & VIF \\
\hline EXP1 & 1.748 & RECOM1 & 1.873 & SATIS1 & 2.181 & LOYAL1 & 1.874 & REPUR1 & 2.276 \\
\hline EXP2 & 1.909 & RECOM2 & 1.980 & SATIS2 & 1.864 & LOYAL2 & 2.592 & REPUR2 & 2.215 \\
\hline EXP3 & 1.717 & RECOM3 & 2.084 & SATIS3 & 2.095 & LOYAL3 & 2.869 & REPUR3 & 2.476 \\
\hline EXP6 & 1.797 & & & SATIS4 & 2.052 & LOYAL4 & 2.951 & & \\
\hline EXP8 & 1.636 & & & & & LOYAL5 & 2.337 & & \\
\hline EXP9 & 1.732 & & & & & LOYAL6 & 2.404 & & \\
\hline \multirow[t]{2}{*}{ EXP10 } & 1.993 & & & & & LOYAL8 & 1.725 & & \\
\hline & & & & & & LOYAL9 & 1.754 & & \\
\hline
\end{tabular}


alpha value of 0.696 is close to acceptable. Cronbach's coefficients greater than 0.90 indicate exceptional internal consistency, greater than 0.80 indicates strong internal consistency, greater than 0.70 indicates acceptable internal consistency, greater than 0.60 indicates doubtful internal consistency, greater than 0.50 indicates poor internal consistency, and less than 0.50 indicates unacceptable internal consistency, according to George and Mallery 2003 cited in Saidi \& Siew, 2019).

HTMT was more successful at detecting discriminant validity. The accepted correlation value for HTMT is below 0.9. As a result, Table 2 below shows the suitable value of HTMT since the value obtained is below 0.9. As a result, the discriminant validity test is deemed valid.

PLS-SEM calculates the Variance Inflation Factor (VIF) in Common Method Bias testing. The VIF statistic indicates the effect of additional independent variables on the standard error of the regression coefficient. The outer VIF value, as shown in Table 3, identifies the indicator variables that can be evaluated regardless of bias or multicollinearity.

Additionally, Podsakoff et al. (2012) argue that Harman's single-factor test is the technique most frequently used to determine CMV infection in a single-method study design. When the variance exceeds 50\%, bias exists. Table 4 illustrates the results of the Common Method Variance measurement in the SPSS application using factor analysis, indicating that the variable is appropriate because the percent variance is less than $50 \%$.

Table 4. CMV

\begin{tabular}{c:c:c}
\hline & \multicolumn{3}{c}{ Total Variance Explained } \\
\hline Total & \% Variance & \% Cumulative \\
\hline 21.106 & 39.82 & 39.82 \\
\hline
\end{tabular}

\subsection{Structural model}

According to Hair et al. (2019), an $\mathrm{R}^{2}$ value of 0.75 indicates that the product is substantial in a marketing study. If the $\mathrm{R}^{2}$ value is 0.50 , it falls into the medium category; if it is 0.25 , it falls into the weak category. Table 5 will include the $\mathrm{R}^{2}$ value for each variable.
Table 5. $R^{2}$ and $Q^{2}$

\begin{tabular}{l|c:c:c}
\hline \multicolumn{1}{c}{ Variable } & $\boldsymbol{R}^{\mathbf{2}}$ & $\boldsymbol{R}^{\mathbf{2}}$ Adjusted & $\boldsymbol{Q}^{\mathbf{2}}$ \\
\hline Brand Communication & 0.527 & 0.525 & 0.356 \\
\hdashline Brand Experience & 0.562 & 0.561 & 0.313 \\
\hline Brand Performance & 0.668 & 0.666 & 0.339 \\
\hline
\end{tabular}

The $R^{2}$ adjusted value of 0.525 in Table 5 indicates that brand innovation can explain brand communication by 52.5 percent. Thus, the $R^{2}$ adjusted value of 0.561 for the brand experience variables indicates that the brand communication variable can clarify the brand experience variable by 56.1 percent. The adjusted $\mathrm{R}^{2}$ value of 0.666 for brand performance shows that 66.6 percent of the variance in brand innovation, dynamic marketing capability, brand communication, and brand experience can be explained by the brand performance variable. In this analysis, predictive relevance is evaluated by blindfolding the dependent variable until it produces a value greater than the rule of thumb $Q^{2}>0$, demonstrating predictive relevance. The effects of the data processing are shown in Table 5. The value of $Q^{2}$ indicates that the endogenous constructs, brand communication is 0.356 , brand experience is 0.313 , and brand performance is 0.339 , all of which are greater than 0 , indicating that the route model prediction is valid. Additionally, the predictive significance of the structural model is $0.02,0.15$, and 0.35 , indicating that the model is weak, moderate, or strong. The predictive relevance value achieved indicates that the model is of moderate quality.

The goodness of fit metric places a premium on the comparison of the anticipated value to the variable's observed value. Additionally, when a model is validated to reflect empirical evidence adequately, the goodness of fit (GOF) statistic can be used to determine its applicability. The GOF value is computed as follows (Ghozali \& Latan, 2015):

$$
\begin{aligned}
& \text { GOF }=\sqrt{\overline{\text { Communality }} \cdot \overline{R^{2}}}, \\
& G O F=\sqrt{\overline{0.627} \cdot \overline{0.586}}=0.606 .
\end{aligned}
$$

The GOF value of 0.606 indicates that the empirical data is appropriate and matches the model. The SRMR is a suitable model component that estimates the applicability of the measured model (good fit). It estimates the observed difference between the correlation matrix and the 
Table 6. Hypothesis testing

\begin{tabular}{|c|c|c|c|c|}
\hline Hypotheses & $\begin{array}{l}\text { Original } \\
\text { Sample }\end{array}$ & T-statistics & Sig P-Value & Result \\
\hline Brand Innovation $\rightarrow$ Brand Communication & 0.282 & 5.161 & 0.000 & Supported \\
\hline DMC $\rightarrow$ Brand Communication & 0.493 & 9.221 & 0.000 & Supported \\
\hline Brand Communication $\rightarrow$ Brand Experience & 0.750 & 31.800 & 0.000 & Supported \\
\hline Brand Experience $\rightarrow$ Brand Performance & 0.552 & 12.932 & 0.000 & Supported \\
\hline Brand Communication $\rightarrow$ Brand Experience $\rightarrow$ Brand Performance & 0.414 & 11.766 & 0.000 & Supported \\
\hline Brand Innovation $\rightarrow$ Brand Performance & 0.206 & 4.994 & 0.000 & Supported \\
\hline DMC $\rightarrow$ Brand Performance & 0.151 & 2.931 & 0.002 & Supported \\
\hline
\end{tabular}

correlation matrix implied by the model. As a result, SRMR is frequently referred to as the average magnitude of reflected fluctuations. If the SRMR value is less than 0.08 (Hair Jr. et al., 2019) or less than 0.1 (Garson, 2016), the model is more appropriate or a good fit. The fit model results in this study indicate that the SRMR value of 0.096 is less than 0.1 , indicating that the data fit the model rather well.

The result of the hypothesis testing is shown in Table 6. Hypotheses 1, 2, 3, 4, 5, 6, and 7 are acceptable as long as the T-statistic is greater than 1.96 and the $\mathrm{p}$-value is less than 0.05 .

\section{DISCUSSION}

The first hypothesis asserts that brand innovation improves brand communication. As shown in Table 6, this hypothesis is accepted because the T-statistic exceeds 1.96, equaling 5.161, and the $\mathrm{p}$-value is less than 0.05 , equaling zero. According to the path coefficient data from the original study, brand innovation has a 0.282 direct effect on brand communication.

The second hypothesis states that dynamic marketing capability benefits brand communication. As shown in Table 6, this hypothesis is accepted since the T-statistic value is more than 1.96 , equals 9.221 , and the p-value is less than 0.05 , which is .000. Therefore, the direct influence of dynamic marketing capability on brand communication is 0.493 , based on the original sample data from the route coefficient.

According to the third hypothesis in this study, brand communication has a favorable effect on brand experience. This hypothesis is supported by the fact that the T-statistic is greater than 1.96 , which equals 31.800 , and the p-value is less than 0.05 , which equals 0.000 . Therefore, according to the route coefficient's original sample data, brand communication directly affects brand experience of 0.750 .

The fourth hypothesis is that brand experience improves brand performance. As shown in Table 6, this hypothesis is supported since the T-statistic value is more than 1.96, which $=12.932$, and the p-value is less than 0.05 , which equals 0.000 . According to the path coefficient's first sample data, brand experience significantly affects brand performance of 0.552 .

The fifth hypothesis in this study claims that through brand experience, brand communication has a beneficial effect on brand performance. As shown in Table 6, this hypothesis is accepted because the T-statistic exceeds 1.96, which equals 11.766 , and the p-value is less than 0.05 , which is .000 . As established by the original sample data from the route coefficient, brand communication directly affects brand performance of 0.414 .

The sixth hypothesis asserts that brand innovation improves brand performance. As shown in Table 6, this hypothesis is accepted because the T-statistic exceeds 1.96, which equals 4.994 , and the p-value is less than 0.05 , which equals .000 . As established by the original sample data from the path coefficient, the direct influence of brand innovation on brand performance is 0.206 .

The seventh hypothesis is that dynamic marketing capability improves brand performance. This theory is confirmed by the T-statistic value above 1.96 , which equals 2.931 , and the p-value being less than 0.05 , which equals 0.002 . Therefore, accord- 
ing to the path coefficient's original sample results, dynamic marketing capability has a 0.151 direct effect on brand performance.

According to the brand innovation variable analysis, if a hotel wishes to capture market share from millennials and generation $\mathrm{Z}$, it must innovate by offering new amenities and services. DMC requires hotels to provide accurate and consistent information about their properties in order for guests to make an informed selection. Additionally, hotels must collect feedback from guests to help them improve their marketing strategy. Following that, hotels are advised to adapt culturally to their surroundings to attract the appropriate market. Finally, hoteliers should use tempting advertising and incentives to entice guests to stay at their property. According to brand experience analysis, consumers can have a more pleasant experience at a hotel by giving the best service available, such as more courteous and concerned hotel staff.

Additionally, hotels must optimize their operations, innovation, and marketing efforts to entice guests to recommend the hotel to others eventually. Hotels should maintain their performance and ensure that their guests have a positive hotel experience. Additionally, hotels must supply services commensurate with the marketed and promoted features to entice repeat customers. Finally, hotels are advised to ensure that their services comply with the standards established and presented, instilling a strong desire in prospective customers to remain at the hotel.

\section{CONCLUSION}

This study aimed to develop a model of brand innovation, dynamic marketing skills, brand communication, and brand experience in 3-5 star international hotels and correlate these factors with brand performance. Brand experience will be a moderator in the relationship between brand communication and brand performance. The model's conclusions are crucial for the study as well as the performance and development of global hotel industry brands, particularly in terms of consumer responsiveness. This discovery is likely to contribute to creating a conceptual model combining brand innovation, dynamic marketing capability, brand communication, brand experience, and brand performance in the global hotel industry. This study lays the theoretical groundwork for dynamic marketing capabilities and brand performance. The purpose of this study is to analyze the relationship between brand innovation, dynamic marketing capabilities, brand communication, brand experience, and brand performance, with a focus on the hospitality industry's brand management in the context of global branding and marketing.

This study was not without limitations. The research object was respondents who have stayed at one of the 3-5 star international hotels. Obtaining respondents who fit the necessary criteria, on the other hand, is not easy. It could be due to potential differences in the positioning and segmentation of foreign threeto five-star hotels. Additionally, because this research paradigm has not been extensively explored, the available sources and hypotheses are relatively limited. Following that, the study object must be adjusted to represent the perceptions of the local audience regarding 3-5 star foreign hotels. To effect these improvements, future studies must ascertain the level of knowledge among the local community with the hotel's reputation (stars) or origin (domestic or international). By boosting the number of respondents and the generalizability of the findings, familiar research objects may help the continuation of the study. Additionally, future research is planned to examine extending the duration of the study in order to acquire the best findings and to identify other ideas that support the research model's hypothesis.

\section{AUTHOR CONTRIBUTIONS}

Conceptualization: Evo Sampetua Hariandja.

Formal analysis: Evo Sampetua Hariandja.

Investigation: Evo Sampetua Hariandja, Lusiana Sartika. 
Methodology: Evo Sampetua Hariandja.

Project administration: Lusiana Sartika.

Resources: Evo Sampetua Hariandja, Lusiana Sartika.

Software: Evo Sampetua Hariandja, Lusiana Sartika.

Supervision: Evo Sampetua Hariandja, Lusiana Sartika.

Validation: Evo Sampetua Hariandja.

Visualization: Lusiana Sartika.

Writing - original draft: Evo Sampetua Hariandja.

Writing - review \& editing: Evo Sampetua Hariandja, Lusiana Sartika.

\section{REFERENCES}

1. Aaker, D. (2007). Innovation: Brand it or Lose it. California Management Review, 50(1), 8-24. Retrieved from https:// www.deepdyve.com/lp/sage/ innovation-brand-it-or-lose-itKxYrzIR8Wy?key=sage

2. Anguera-Torrell, O., AznarAlarcón, J. P., \& Vives-Perez, J. (2021). COVID-19: hotel industry response to the pandemic evolution and to the public sector economic measures. Tourism Recreation Research, 46(2), 148157. https://doi.org/10.1080/02508 281.2020.1826225

3. Asy'ari, A. H., \& Jayen, F. (2020). Faktor-Faktor yang Memengaruhi Loyalitas Merek Handphone Merek Samsung di Kalimantan Selatan. Jurnal Pundi, 3(3), 235248. (In Indonesian). https://doi. org/10.31575/jp.v3i3.198

4. Bhasin, H. (2021, April 21). What is Brand Communication? Advantages of Brand Communication. Marketing91. Retrieved from https://www. marketing91.com/brand-communication/

5. BPS. (2020, September 22). Jumlah Tamu Indonesia pada Hotel Bintang (Ribu Orang). (In Indonesian). Retrieved from https://www.bps.go.id/indicator/16/328/1/jumlah-tamu-indonesia-pada-hotel-bintang.html

6. Brakus, J., Schmitt, B. H., \& Zarantonello, L. (2009). Brand Experience: What Is It? How Do We Measure It? Does It Affect Loyalty? Journal of Marketing, 73(3).

7. Casidy, R., Wymer, W., \& O'Cass, A. (2018). Enhancing hotel brand performance through fostering brand relationship orientation in the minds of consumers. Tourism Management, 66, 72-84. https://doi.org/10.1016/j.tourman.2017.11.008

8. Chien, Y.-C. (2013). The Influences of Brand Innovation on Customer Value: Using Double-Distal Mediators of Brand Perception and Brand Equity. Journal of Global Business Management, 9(2), 53-70. Retrieved from http://www.jgbm. org/page/6\%20Yung-Chieh\%20 Chien.pdf

9. Chinomona, R. (2016). Brand communication, brand image and brand trust as antecedents of brand loyalty in Gauteng Province of South Africa. African Journal of Economic and Management Studies, 7(1), 124-139. Retrieved from https://ideas.repec.org/a/ eme/ajempp/v7y2016ilp124-139. html

10. Coelho, F. J. F., Bairrada, C. M., \& de Matos Coelho, A. F. (2020). Functional brand qualities and perceived value: The mediating role of brand experience and brand personality. Psychology and Marketing, 37(1), 41-55. https:// doi.org/10.1002/mar.21279

11. Elsharnouby, T. H., \& Elbanna, S. (2021). Change or perish: Examining the role of human capital and dynamic marketing capabilities in the hospitality sector. Tourism Management, 82, 104184. https://doi.org/10.1016/j. tourman.2020.104184

12. Fazal-e-Hasan, S. M., Ahmadi, H., Kelly, L., \& Lings, I. N. (2019).
The role of brand innovativeness and customer hope in developing online repurchase intentions. Journal of Brand Management, 26(2), 85-98. https://doi. org/10.1057/s41262-018-0122-4

13. Foroudi, P. (2019). Influence of brand signature, brand awareness, brand attitude, brand reputation on hotel industry's brand performance. International Journal of Hospitality Management, 76(A), 271-285. https://doi. org/10.1016/j.ijhm.2018.05.016

14. Garson, G. D. (2016). Partial Least Squares: Regression \& Structural Equation Models. Statistical Publishing Associates.

15. George, D., \& Mallery, P. (2003) SPSS for Windows step by step: A simple guide and reference. 11.0 update. Allyn \& Bacon.

16. Ghozali, I., \& Latan, H. (2015). Partial Least Squares Konsep, Teknik dan Aplikasi Menggunakan Program SmartPLS 3.0. Universitas Diponegoro.

17. Gómez-Suárez, M., \& Veloso, M. (2020). Brand experience and brand attachment as drivers of WOM in hospitality. Spanish Journal of Marketing - ESIC, 24(2), 231-246. https://doi.org/10.1108/ SJME-12-2019-0106

18. Grant, J. (2006). The Brand Innovation Manifesto: How to Build Brands, Redefine Markets and Defy Conventions. John Wiley \& Sons Ltd. https://doi. org/10.1002/9781119209324

19. Hair Jr., J. F., Black, W. C., Babin, B. J., Anderson, R. E., Black, W. C., \& Anderson, R. E. (2019). 
Multivariate Data Analysis ( $8^{\text {th }}$ ed.). Cengage Learning.

20. Hanifah, S., Rahayu, A., \& Dirgantari, P. D. (2018). Gambaran Brand Experience Dan Brand Love Iphone Pada Komunitas Fanspage Facebook Iphone Indonesia. Journal of Business Management Education (JBME), 3(1), 1-10. (In Indonesian). https://doi. org/10.17509/jbme.v3i1.14242

21. Hariandja, E. S. (2016a). Service Excellence through Dynamic Marketing Capability. Proceedings of the 2016 Global Conference on Business, Management and Entrepreneurship. Atlantis Press. https://doi.org/10.2991/ gcbme-16.2016.79

22. Hariandja, E. S. (2016b). The Interaction Between Dynamic Marketing Capability and Service Innovation Capability on Performance. Proceedings of the 2016 Global Conference on Business, Management and Entrepreneurship. Atlantis Press. https://doi.org/10.2991/ gcbme-16.2016.73

23. Hariandja, E. S., Simatupang, T. M., Nasution, R. A., \& Larso, D. (2014). Dynamic marketing and service innovation for service excellence. Gadjah Mada International Journal of Business, 16(2), 143-166. https://doi. org/10.22146/gamaijb.5461

24. Hoque, M. T., Ahammad, M. F., Tzokas, N., \& Gabay, G. (2021). Dimensions of dynamic marketing capability and export performance. Journal of Knowledge Management, 25(5), 1219-1240. https://doi. org/10.1108/JKM-09-2019-0482

25. Hsieh, S. H., \& Chang, A. (2016). The Psychological Mechanism of Brand Co-creation Engagement. Journal of Interactive Marketing, 33, 13-26. https://doi.org/10.1016/j. intmar.2015.10.001

26. Huang, C.-C., Wang, Y.-M., Wu, T.-W., \& Wang, P.-A. (2013). An Empirical Analysis of the Antecedents and Performance Consequences of Using the Moodle Platform. International Journal of Information and Education Technology, 3(2), 217221. https://doi.org/10.7763/ ijiet.2013.v3.267
27. Hussein, A. S. (2018). Effects of brand experience on brand loyalty in Indonesian casual dining restaurant: Roles of customer satisfaction and brand of origin. Tourism and Hospitality Management, 24(1), 119-132. https://doi.org/10.20867/ thm.24.1.4

28. Idris, M. (2020, June 9). Siasat Hotel di Daerah Bertahan di Tengah Pandemi Covid-19. Kompas. (In Indonesian). Retrieved from https://money.kompas.com/ $\mathrm{read} / 2020 / 06 / 09 / 160208926 /$ siasat-hotel-di-daerah-bertahandi-tengah-pandemi-covid19 ? page $=$ all

29. Iyer, P., Davari, A., \& Paswan, A. (2018). Determinants of brand performance: The role of internal branding. Journal of Brand Management, 25(3), 202-216. https://doi.org/10.1057/s41262018-0097-1

30. Japutra, A., \& Situmorang, R. (2021). The repercussions and challenges of COVID-19 in the hotel industry: Potential strategies from a case study of Indonesia. International Journal of Hospitality Management, 95, 102890. https://doi.org/10.1016/j. ijhm.2021.102890

31. Jiménez-Jiménez, D., \& SanzValle, R. (2011). Innovation, organizational learning, and performance. Journal of Business Research, 64(4), 408417. https://doi.org/10.1016/j. jbusres.2010.09.010

32. Kang, J., Manthiou, A., Sumarjan, N., \& Tang, L. R. (2017). An Investigation of Brand Experience on Brand Attachment, Knowledge, and Trust in the Lodging Industry. Journal of Hospitality Marketing and Management, 26(1), 1-22. https://doi.org/10.1080/19368623. 2016.1172534

33. Khan, I., \& Fatma, M. (2017). Antecedents and outcomes of brand experience: An empirical study. Journal of Brand Management, 24(5), 439-452. https://doi.org/10.1057/s41262017-0040-x
34. Konwar, Z., Papageorgiadis, N., Ahammad, M. F., Tian, Y., McDonald, F., \& Wang, C. (2017). Dynamic marketing capabilities, foreign ownership modes, sub-national locations and the performance of foreign affiliates in developing economies. International Marketing Review, 34(5), 674-704. https://doi. org/10.1108/IMR-01-2016-0004

35. Liu, K. N., Hu, C., Lin, M. C., Tsai, T. I., \& Xiao, Q. (2020). Brand knowledge and non-financial brand performance in the green restaurants: Mediating effect of brand attitude. International Journal of Hospitality Management, 89, 102566. https://doi. org/10.1016/j.ijhm.2020.102566

36. Mason, D., Cox, C., \& Roberts, E. (2006). Guest perceptions of hotel loyalty. Elizabeth Roberts.

37. Ngatno, N. (2017). Effect of Brand Communication and Experience on Loyalty: Mediating Effect of Brand Satisfaction and Trust. (Case Study of Customers of Inul Vista Karaoke, Semarang, Central Java, Indonesia). Archives of Business Research, 5(4), 5567. https://doi.org/10.14738/ abr. 54.2828

38. O’Neill, J. W., \& Xiao, Q. (2006). The Role of Brand Affiliation in Hotel Market Value. Cornell Hotel and Restaurant Administration Quarterly, 47(3), 210-223. https://doi. org/10.1177/0010880406289070

39. O'Neill, J.W., \& Mattila, A.S. (2004). Hotel branding strategy: Its relationship to guest satisfaction and room revenue. Journal of Hospitality and Tourism Research, 28(2), 156-165.

40. Pappu, R., \& Quester, P. G. (2016). How does brand innovativeness affect brand loyalty? European Journal of Marketing, 50(1/2), 2-28. https://doi.org/10.1108/EJM-012014-0020

41. Podsakoff, P. M., MacKenzie, S. B., \& Podsakoff, N. P. (2012). Sources of method bias in social science research and recommendations on how to control it. Annual Review of Psychology, 63, 539-569. https://doi.org/10.1146/annurevpsych-120710-100452 
42. Reimann, C., Carvalho, F., \& Duarte, M. (2021). The influence of dynamic and adaptive marketing capabilities on the performance of portuguese smes in the b2b international market. Sustainability, 13(2), 579. https:// doi.org/10.3390/su13020579

43. Roespinoedji, D., Afghan Prawira, E. P., Solihin, I., Saudi, M. H. M., \& Alaeddin, O. (2019). Determinants of supply chain performance: Moderating role of firm size in tourism hotel industry in Indonesia. International Journal of Supply Chain Management, 8(1), 219-230. Retrieved from https:// ojs.excelingtech.co.uk/index.php/ IJSCM/article/view/2888

44. Sahin, A., Cemal, Z., \& Hakan, K. (2011). The Effects of Brand Experiences, Trust and Satisfaction on Building Brand Loyalty; An Empirical Research On Global Brands. Procedia Social and Behavioral Sciences, 24, 1288-1301.

45. Saidi, S. S., \& Siew, N. M. (2019). Investigating the Validity and Reliability of Survey Attitude towards Statistics Instrument among Rural Secondary School Students. International Journal of Educational Methodology, 5(4), 651-661. https://doi.org/10.12973/ ijem.5.4.651

46. Shams, R., Alpert, F., \& Brown, M. (2015). Consumer perceived brand innovativeness: Conceptualization and operationalization. European Journal of Marketing, 49(9/10), 1589-1615. https://doi. org/10.1108/EJM-05-2013-0240

47. Suharyanti, Hanathasia, M., \& Fortunisa, A. (2019). Pelatihan Manejemen Komunikasi Merek Kepada Pelaku Usaha Dalam Mendukung City Branding Cirebon. Indonesian Journal of Social Responsibility, 1(2), 61-67. (In Indonesian). https://doi. org/10.36782/ijsr.v1i02.14

48. Takahashi, A., Bulgacov, S., Semprebon, E., \& Giacomini, M. (2017). Dynamic capabilities, Marketing Capability and Organizational Performance. Brazilian Business Review, 14(5), 466-478. https://doi.org/10.15728/ bbr.2017.14.5.1

49. Unurlu, C., \& Uca, S. (2017). The effect of culture on brand loyalty through brand performance and brand personality. International Journal of Tourism Research, 19(6), 672-681. https://doi.org/10.1002/ jtr.2139

50. Walugembe, A., Ntayi, J., Bakunda, G., Ngoma, M., Munene, J., \& Box, P. O. (2017). Dynamic Marketing Capabilities and New Product Adoption; The mediating role of Consumer Based Brand
Equity. International Journal of Scientific Research and Innovative Technology, 4(10), 242-262.

51. Weerawardena, J., O'Cass, A., \& Julian, C. (2006). Does industry matter? Examining the role of industry structure and organizational learning in innovation and brand performance. Journal of Business Research, 59(1), 37-45. https://doi. org/10.1016/j.jbusres.2005.02.004

52. Wiastuti, R. D., Lestari, N. S., Mulyadi, N. B., \& Masatip, A. (2020). The generation $\mathrm{z}$ characteristics and hotel choices. African Journal of Hospitality, Tourism and Leisure, 9(1), 1-14.

53. Wibowo, L. A. (2011). Experential Marketing dan Branded Customer Experience Kaitannya Dengan Loyalitas Pelanggan Restoran dan Café Serta Dampaknya Pada Citra Bandung Sebagai Destinasi Pariwisata Indonesia. Strategic Jurnal Manajemen Pendidikan Bisnis UPI, 10(19), 48-60. (In Indonesian).

54. Xie, K. L., Zhang, Z., Zhang, Z., Singh, A., \& Lee, S. K. (2016). Effects of managerial response on consumer eWOM and hotel performance: evidence from TripAdvisor. International Journal of Contemporary Hospitality Management, 28(9), 20132034. https://doi.org/10.1108/ IJCHM-06-2015-0290 


\section{APPENDIX A}

Table A1. Respondent profile

\begin{tabular}{|c|c|c|}
\hline Description & Frequency & $\%$ \\
\hline \multicolumn{3}{|l|}{ Gender } \\
\hline Male & 198 & $37.4 \%$ \\
\hline Female & 332 & $62.6 \%$ \\
\hline \multicolumn{3}{|l|}{ Age } \\
\hline $15-19$ & 206 & $38.9 \%$ \\
\hline $20-24$ & 272 & $51.3 \%$ \\
\hline $25-29$ & 36 & $6.8 \%$ \\
\hline $30-34$ & 7 & $1.3 \%$ \\
\hline $35-39$ & 3 & $0.6 \%$ \\
\hline$>40$ & 6 & $1.1 \%$ \\
\hline \multicolumn{3}{|l|}{ Domicile } \\
\hline Jakarta & 174 & $32.8 \%$ \\
\hline Bandung & 20 & $3.8 \%$ \\
\hline Tangerang & 187 & $35.3 \%$ \\
\hline Surabaya & 31 & $5.8 \%$ \\
\hline Others & 118 & $22.3 \%$ \\
\hline \multicolumn{3}{|l|}{ Profession } \\
\hline College student & 429 & $80.9 \%$ \\
\hline Entrepreneur & 32 & $6 \%$ \\
\hline Student & 39 & $7.4 \%$ \\
\hline Employee & 28 & $5.3 \%$ \\
\hline Others & 2 & $0.4 \%$ \\
\hline \multicolumn{3}{|l|}{ Marital Status } \\
\hline Single & 502 & $94.7 \%$ \\
\hline Married & 27 & $5.1 \%$ \\
\hline Widower/Widowed & 1 & $0.2 \%$ \\
\hline \multicolumn{3}{|l|}{ Education } \\
\hline Bachelor & 365 & $68.9 \%$ \\
\hline High School & 133 & $25.1 \%$ \\
\hline Diploma & 19 & $3.6 \%$ \\
\hline No school education & 1 & $0.2 \%$ \\
\hline Junior high school & 4 & $0.7 \%$ \\
\hline Doctorate & 1 & $0.2 \%$ \\
\hline Master & 7 & $1.3 \%$ \\
\hline \multicolumn{3}{|c|}{ Monthly Income (in thousands Rp) } \\
\hline$<10.000$ & 427 & $80.6 \%$ \\
\hline $10.000-15.000$ & 44 & $8.3 \%$ \\
\hline $15.000-20.000$ & 28 & $5.2 \%$ \\
\hline $20.000-25.000$ & 12 & $2.3 \%$ \\
\hline$>25.000$ & 19 & $3.6 \%$ \\
\hline \multicolumn{3}{|c|}{ Frequency of Stay/year (in times) } \\
\hline $1-2$ & 354 & $66.8 \%$ \\
\hline $3-4$ & 128 & $24.2 \%$ \\
\hline $5-6$ & 24 & $4.5 \%$ \\
\hline$>6$ & 24 & $4.5 \%$ \\
\hline \multicolumn{3}{|l|}{ Hotel Type } \\
\hline 3 star & 65 & $12.3 \%$ \\
\hline 4 star & 176 & $33.2 \%$ \\
\hline 5 star & 289 & $54.5 \%$ \\
\hline \multicolumn{3}{|l|}{ Travel Companion } \\
\hline With family & 404 & $76.2 \%$ \\
\hline With friends & 69 & $13 \%$ \\
\hline With partner & 19 & $3.6 \%$ \\
\hline For business & 24 & $4.5 \%$ \\
\hline Solo travel & 14 & $2.7 \%$ \\
\hline
\end{tabular}


ฟ Table A2. Outer loadings

\begin{tabular}{|c|c|c|c|c|c|c|c|c|c|c|}
\hline Item & $\begin{array}{c}\text { Brand } \\
\text { Communication }\end{array}$ & $\begin{array}{c}\text { Brand } \\
\text { Experience }\end{array}$ & $\begin{array}{c}\text { Brand } \\
\text { Innovation }\end{array}$ & Learning & $\begin{array}{l}\text { Brand } \\
\text { Loyalty }\end{array}$ & $\begin{array}{c}\text { Brand } \\
\text { Recommendation }\end{array}$ & $\begin{array}{c}\text { Brand } \\
\text { Repurchase }\end{array}$ & $\begin{array}{c}\text { Customer } \\
\text { Satisfaction }\end{array}$ & $\begin{array}{l}\text { Market } \\
\text { Sensing }\end{array}$ & $\begin{array}{l}\text { Targeting \& } \\
\text { Positioning }\end{array}$ \\
\hline COMM1 & 0.808 & & & & & & & & & \\
\hline COMM2 & 0.824 & & & & & & & & & \\
\hline COMM3 & 0.826 & & & & & & & & & \\
\hline COMM4 & 0.826 & & & & & & & & & \\
\hline COMM5 & 0.841 & & & & & & & & & \\
\hline EXP1 & & 0.737 & & & & & & & & \\
\hline EXP10 & & 0.791 & & & & & & & & \\
\hline EXP2 & & 0.768 & & & & & & & & \\
\hline EXP3 & & 0.738 & & & & & & & & \\
\hline EXP6 & & 0.747 & & & & & & & & \\
\hline EXP8 & & 0.724 & & & & & & & & \\
\hline EXPY & & 0.743 & & & & & & & & \\
\hline INNO1 & & & 0.738 & & & & & & & \\
\hline INNO2 & & & 0.756 & & & & & & & \\
\hline INNO3 & & & 0.728 & & & & & & & \\
\hline INNO5 & & & 0.747 & & & & & & & \\
\hline INNO6 & & & 0.761 & & & & & & & \\
\hline LEARN1 & & & & 0.772 & & & & & & \\
\hline LEARN3 & & & & 0.790 & & & & & & \\
\hline LEARN4 & & & & 0.803 & & & & & & \\
\hline LOYAL1 & & & & & 0.740 & & & & & \\
\hline LOYAL2 & & & & & 0.821 & & & & & \\
\hline LOYAL3 & & & & & 0.857 & & & & & \\
\hline LOYAL4 & & & & & 0.853 & & & & & \\
\hline LOYAL5 & & & & & 0.790 & & & & & \\
\hline LOYALE6 & & & & & 0.814 & & & & & \\
\hline LOYALL8 & & & & & 0.706 & & & & & \\
\hline LOYAL9 & & & & & 0.720 & & & & & \\
\hline RECOM1 & & & & & & 0.861 & & & & \\
\hline RECOM2 & & & & & & 0.870 & & & & \\
\hline RECOM3 & & & & & & 0.877 & & & & \\
\hline REPUR1 & & & & & & & 0.888 & & & \\
\hline REPUR2 & & & & & & & 0.884 & & & \\
\hline REPUR3 & & & & & & & 0.903 & & & \\
\hline SATIS1 & & & & & & & & 0.854 & & \\
\hline SATISZ & & & & & & & & 0.818 & & \\
\hline SATIS3 & & & & & & & & 0.848 & & \\
\hline SATIS4 & & & & & & & & 0.846 & & \\
\hline SENS2 & & & & & & & & & 0.789 & \\
\hline SENS3 & & & & & & & & & 0.783 & \\
\hline SENS4 & & & & & & & & & 0.824 & \\
\hline TAPO1 & & & & & & & & & & 0.764 \\
\hline TAPO2 & & & & & & & & & & 0.756 \\
\hline TAPO3 & & & & & & & & & & 0.756 \\
\hline TAPO4 & & & & & & & & & & 0.785 \\
\hline
\end{tabular}


Table A3. Common method variance

\begin{tabular}{|c|c|c|c|c|c|c|}
\hline \multicolumn{7}{|c|}{ Total Variance Explained } \\
\hline \multirow{2}{*}{ Component } & \multicolumn{3}{|c|}{ Initial Eigenvalues } & \multicolumn{3}{|c|}{ Extraction Sums of Squared Loadings } \\
\hline & Total & $\%$ of Variance & Cumulative \% & Total & $\%$ of Variance & Cumulative \% \\
\hline 1 & 21.106 & 39.824 & 39.824 & 21.106 & 39.824 & 39.824 \\
\hline 2 & 3.341 & 6.305 & 46.128 & & & \\
\hline 3 & 2.589 & 4.885 & 51.013 & & & \\
\hline 4 & 1.311 & 2.474 & 53.487 & & & \\
\hline 5 & 1.202 & 2.267 & 55.754 & & & \\
\hline 6 & 1.098 & 2.071 & 57.825 & & & \\
\hline 7 & 1.008 & 1.902 & 59.727 & & & \\
\hline 8 & 0.984 & 1.857 & 61.584 & & & \\
\hline 9 & 0.92 & 1.736 & 63.319 & & & \\
\hline 10 & 0.87 & 1.641 & 64.96 & & & \\
\hline 11 & 0.823 & 1.553 & 66.513 & & & \\
\hline 12 & 0.776 & 1.464 & 67.977 & & & \\
\hline 13 & 0.756 & 1.427 & 69.404 & & & \\
\hline 14 & 0.711 & 1.342 & 70.746 & & & \\
\hline 15 & 0.685 & 1.293 & 72.039 & & & \\
\hline 16 & 0.656 & 1.237 & 73.276 & & & \\
\hline 17 & 0.648 & 1.222 & 74.498 & & & \\
\hline 18 & 0.634 & 1.196 & 75.694 & & & \\
\hline 19 & 0.615 & 1.161 & 76.856 & & & \\
\hline 20 & 0.59 & 1.112 & 77.968 & & & \\
\hline 21 & 0.571 & 1.077 & 79.045 & & & \\
\hline 22 & 0.562 & 1.06 & 80.106 & & & \\
\hline 23 & 0.529 & 0.999 & 81.104 & & & \\
\hline 24 & 0.505 & 0.953 & 82.058 & & & \\
\hline 25 & 0.487 & 0.919 & 82.977 & & & \\
\hline 26 & 0.472 & 0.891 & 83.868 & & & \\
\hline 27 & 0.469 & 0.885 & 84.753 & & & \\
\hline 28 & 0.458 & 0.864 & 85.618 & & & \\
\hline 29 & 0.44 & 0.83 & 86.448 & & & \\
\hline 30 & 0.427 & 0.806 & 87.253 & & & \\
\hline 31 & 0.413 & 0.779 & 88.033 & & & \\
\hline 32 & 0.39 & 0.737 & 88.769 & & & \\
\hline 33 & 0.387 & 0.73 & 89.5 & & & \\
\hline 34 & 0.375 & 0.708 & 90.208 & & & \\
\hline 35 & 0.367 & 0.692 & 90.9 & & & \\
\hline 36 & 0.357 & 0.673 & 91.573 & & & \\
\hline 37 & 0.353 & 0.667 & 92.24 & & & \\
\hline 38 & 0.346 & 0.652 & 92.892 & & & \\
\hline 39 & 0.328 & 0.619 & 93.511 & & & \\
\hline 40 & 0.322 & 0.608 & 94.12 & & & \\
\hline 41 & 0.299 & 0.564 & 94.684 & & & \\
\hline 42 & 0.293 & 0.552 & 95.236 & & & \\
\hline 43 & 0.283 & 0.533 & 95.769 & & & \\
\hline 44 & 0.268 & 0.506 & 96.275 & & & \\
\hline 45 & 0.26 & 0.49 & 96.765 & & & \\
\hline 46 & 0.25 & 0.471 & 97.236 & & & \\
\hline 47 & 0.24 & 0.453 & 97.69 & & & \\
\hline 48 & 0.237 & 0.447 & 98.137 & & & \\
\hline 49 & 0.223 & 0.421 & 98.557 & & & \\
\hline 50 & 0.214 & 0.405 & 98.962 & & & \\
\hline 51 & 0.196 & 0.37 & 99.332 & & & \\
\hline 52 & 0.191 & 0.361 & 99.692 & & & \\
\hline 53 & 0.163 & 0.308 & 100 & & & \\
\hline
\end{tabular}


Innovative Marketing, Volume 18, Issue 1, 2022

Table A4. Model fit

\begin{tabular}{l|c|c}
\hline \multicolumn{1}{c|}{ Description } & Saturated & Estimated \\
\hline SRMR & 0.086 & 0.096 \\
\hline d_ULS & 20.081 & 0.142 \\
\hline rms Theta & & 25.111 \\
\hline
\end{tabular}

Table A5. Predictive relevance

\begin{tabular}{l|c|c|c}
\hline \multicolumn{1}{c|}{ Variable } & SSO & SSE & $\mathbf{Q}^{\mathbf{2}}$ \\
\hline Brand Communication & 2650,000 & 1707,608 & 0.356 \\
\hline Brand Experience & 3710,000 & 2547,659 & 6 \\
\hline Brand Performance & 9540,000 & 6302,995 & 0.313 \\
\hline
\end{tabular}

